\title{
海岸護岸における越波量の時間的変動特性 TIME-RELATED FLUCTUATION OF WAVE OVERTOPPING DISCHARGE ON SEAWALLS
}

\author{
井上裕規 1 ・井上雅夫 2 ・玉田 崇1 \\ Hironori INOUE, Masao INOUE and Takashi TAMADA
}

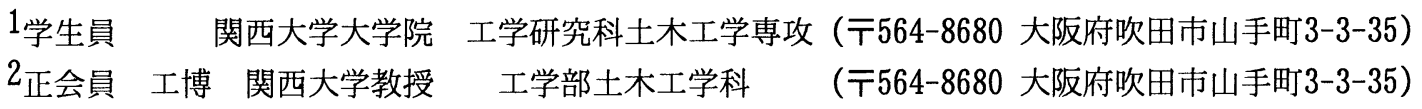

The purpose of this study is to clarify the time-related fluctuation of wave overtopping discharge on seawalls by random wave using many experimental results until now.

Seawall shape with the object in this study are upright seawall, upright seawall with set back parapet, perforated upright seawall and gentle slope-type seawall.

To begin with, representative wave overtopping discharge by the definition equal to the representative wave height was obtained for these seawalls. Next, the shape parameter as the weibull distribution applied appearance probability distribution of wave overtopping discharge of individual wave was required. In addition, the relationship between this shape parameter and the relative water depth, wave steepness, relative crest height, wind velocity, etc. are discussed for the case of each seawall.

Key Words : wave overtopping, upright seawall, wave absorbing upright seawall, gentle slope-type seawall

\section{1. 緒 言}

我が国の海岸には,波浪,高潮および津波などによ る自然災害から住民の生命や財産を守るため,各種 の海岸護岸が建設されている.なかでも,越波防止を 目的とした海岸護岸の機能設計に際しては,合田ら ${ }^{11}$ による越波流量の推定図表が用いられることが多い。 しかし,これは数十分間程度の平均的な越波流量を 与えるものであって,短時間,例えば 1 波当たりの越 波流量は,合田らの推定図表による值よりも,かなり 大きくなる場合が考えられる.したがって,護岸背後 に十分な排水施設がなかったり，逆に人家などがあ る場合にはきわめて危険である。

このようなことから,この研究では,著者ら ${ }^{21 〜 6) ~ か ゙ ~}$ 従来行ってきた各種の海岸護岸の不規則波による越 波実験の結果を用い,越波量の時間的変動特性を明 らかにしようとした。

\section{2. 解析に用いた実験結果の説明と解析方法}

この研究で対象とした海岸護岸は,直立護岸,パラ ペット後退型護岸,有孔壁式護岸, 勾配が3割および5 割の緩傾斜護岸の 5 種類である.それそれれ実験結 果については,参考文献2)〜6)において,すでに詳述 しているので,ここでは,その概要だけについて簡単
に述べよう。

実験では, 2 次元不規則波造波水槽（長さ $30 \mathrm{~m}$, 幅 $0.7 \mathrm{~m}$, 深さ $1.0 \mathrm{~m})$ 内に, 図-1(a)〜 (e)に示した 5 種類 の模型護岸を設置して,それらの護岸を越波する 1 波ごとの越波量を測定した.入射波は有義波周期Tが

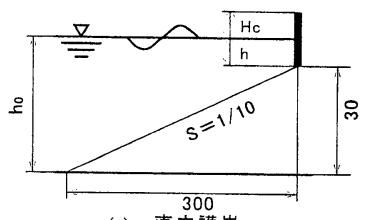

(a) 直立護岸

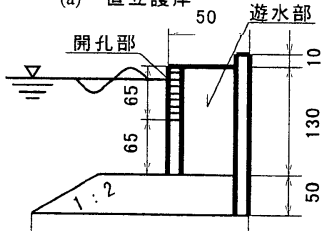

(c) 有孔壁式護岸

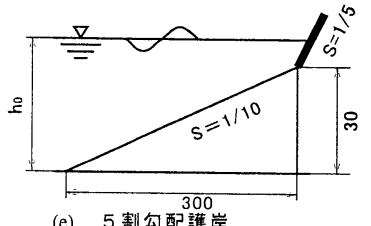

(e) 5 割勾配護岸

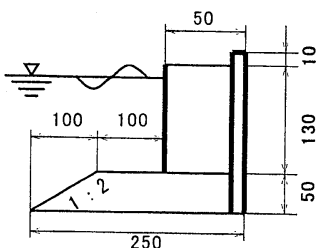

(b) パラペット後退型讙㟶

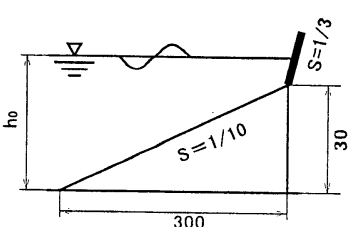

(d) 3 割勾配諉岸 図-1＼cjkstart模型護岸 
1.0sのBretschneider・光易型スペクトルを有する 不規則波である.表一 1 には,そのほかの実験条件を， それぞれの護岸ごとに示した。

なお,こうした越波実験では造波板と模型護岸間 の多重反射などのためにサーフビートが増幅され， 護岸前面の水位が変動していることは間違いない。 しかし,この影響を考慮して,各護岸の 1 波ごとの越 波量を合理的に補正することは困難である.また,す べての実験において,造波板から護岸の設置位置ま での距離, 入射波周期および一様水深部の水深など の実験規模や越波量の測定時間に大きな違いはない。 こうしたことから,ここでは前述の方法で測定した 越波量の実験值をそのまま以下の解析に用いること にした。

まず,それぞれの護岸における 1 波ごとの越波量 から代表波法と同じ定義による $Q_{\max }, Q_{1 / 10,} Q_{1 / 3}$ およびQ を求めた.さらに,それらを用いて代表越波量比を計 算した.次に, 1 波ごとの越波流量の出現頻度分布を 求め,それにWeibull分布を当てはめた場合の形状母 数 $\alpha$ を護岸の形状ごとに求めた.なお,この形状母数 は,いずれの場合にも実験值をもとに確率密度を求 める段階で形状母数を0.1ずつ変化させて計算し,そ れと実験値との間で $\chi^{2}$ 検定を行って,その検定值が 最小になるものを採用した.このようにして,各種護 岸についての代表越波量比やWeibull分布の形状母 数と越波量に及ぼす諸要素との関係について検討を 行った.なお,以上の解析に際しては,すべて越波し た波だけを対象とした。

\section{表-1 実験条件}

\begin{tabular}{|c|c|c|c|}
\hline \multicolumn{2}{|l|}{ 護岸形状 } & 直立護岸 & パラペット後退型護岸 \\
\hline 有義波形勾配 & $\mathrm{H}_{0} / \mathrm{L}_{0}$ & $0.02,0.03,0.04,0.05$ & 0.04 \\
\hline 護岸天端高 & $\mathrm{H}_{\mathrm{c}}(\mathrm{cm})$ & $1.3,3.1,4.7,6.2,7.8$ & 3.1 \\
\hline のり先水深 & $h(\mathrm{~cm})$ & $0,1,2,3,4$ & $15,16,17,18$ \\
\hline 一様水深 & $h_{0}(\mathrm{~cm})$ & $30,31,32,33,34$ & $30,31,32,33$ \\
\hline 相対護岸天端高 & $\mathrm{H}_{\mathrm{c}} / \mathrm{H}_{0}$ & $0.2,0.4,0.6,0.8,1.0$ & 0.5 \\
\hline のり先水深·波長比 & $h / L_{0}$ & $0,0.006,0.013,0.019,0.026$ & $0.096,0.103,0.109,0.115$ \\
\hline 無次元風速 & $\mathrm{V} / \sqrt{\mathrm{g}} \mathrm{H}_{0}$ & $0,4,8$ & $0,3,6$ \\
\hline 海浜公配 & $\mathrm{s}$ & $1 / 10$ & $1 / 50$ \\
\hline 無次元遊水部幅 & $\mathrm{B} / \mathrm{H}_{0}$ & - & 0.8 \\
\hline \multicolumn{2}{|l|}{ 護岸形状 } & 直孔壁式護岸 & 3割および5割勾配護岸 \\
\hline 有義波形勾配 & $\mathrm{H}_{0} / \mathrm{L}_{0}$ & $0.03,0.04,0.05$ & 0.04 \\
\hline 護岸天端高 & $H_{0}(\mathrm{~cm})$ & $2.3,3.1,3.9$ & 6.2 \\
\hline のり先水深 & $\mathrm{h}(\mathrm{cm})$ & $15,16,17,18$ & $0,1,2,3,4$ \\
\hline 一様水深 & $h_{0}(\mathrm{~cm})$ & $30,31,32,33$ & $30,31,32,33,34$ \\
\hline 相対護岸天端高 & $\mathrm{H}_{\mathrm{c}} / \mathrm{H}_{0}$ & 0.5 & 1.0 \\
\hline のり先水深·波長比 & $h / L_{0}$ & $0.096,0.103,0.109,0.115$ & $0,0.006,0.013,0.019,0.026$ \\
\hline 無次元風速 & $\mathrm{V} / \sqrt{\mathrm{gH}_{0}}$ & $0,3,6$ & $0,4,8$ \\
\hline 海浜勾配 & $\mathrm{s}$ & $1 / 50$ & $1 / 10$ \\
\hline 護岸前面の開孔率 & $\mathrm{K}(\%)$ & $0,15,30,45$ & $=$ \\
\hline 無次元遊水部幅 & $\mathrm{B} / \mathrm{H}_{0}$ & $0.31,0.69,0.8$ & - \\
\hline 無次元粒径 & $d / H_{0}$ & - & $0,0.001,0.013,0.058,0.236$ \\
\hline
\end{tabular}

\section{3. 海岸護岸における越波量の時間的変動特性}

\section{(1) 直立護岸}

図-1(a)に示したように, $1 / 10$ 傾斜海浜上に直立 護岸を設置した場合について検討する.

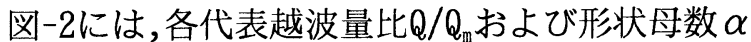
とのり先水深・波長比 $\mathrm{h} / \mathrm{L}_{0}$ との関係を示した.

これによると, $Q_{1 / 3} / Q_{m}$ と $Q_{1 / 10} / Q_{m}$ は, $\mathrm{h} / \mathrm{L}_{0}$ が0.006の場
合に,それぞれ2と5の最大值を示すが,これらには $\mathrm{h} / \mathrm{L}_{0}$ による変動は小さい.一方, $\mathrm{Q}_{\max } / \mathrm{Q}_{\mathrm{m}}$ にはh $/ \mathrm{L}_{0}$ によ る変動が大きく, $\mathrm{h} / \mathrm{L}_{0}$ が0.013の場合に最大值10を示

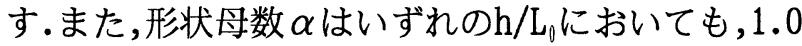
以上となり,特に, $\mathrm{h} / \mathrm{L}_{0}$ が0.019の場合に 1.3 の最大值 を示す.なお,形状母数 $\alpha$ が小さくなることは,平均 越波量よりも大きなものが現れる確率が高くなるこ とを意味している.したがって,たとえば, $\mathrm{h} / \mathrm{L}_{0}$ が変 化しても $\alpha$ の值が変化しないか, あるいは大きくな るものが優れた越波低減機能を有していることにな る.

図-3には,各代表越波量比Q $/ Q_{\mathrm{m}}$ および形状母数 $\alpha$ と波形勾配 $\mathrm{H}_{0} / \mathrm{L}_{0}$ との関係を示した.

これによると, $Q_{1 / 3} / Q_{\mathbb{m}}$ と $Q_{1 / 10} / Q_{\mathbb{m}}$ は, $\mathrm{H}_{0} / \mathrm{L}_{0}$ が0.04の場 合に,それぞれ2と4の最大值を示すが,これらには $\mathrm{H}_{0} / \mathrm{L}_{0}$ による変動は小さい.一方, $\mathrm{Q}_{\max } / \mathrm{Q}_{\mathbf{m}}$ は $\mathrm{H}_{0} / \mathrm{L}_{0}$ による 変動が大きく, $\mathrm{H}_{0} / \mathrm{L}_{0}$ が0.03の場合に約 10 の最大值を 示す.形状母数 $\alpha$ は $\mathrm{H}_{0} / \mathrm{L}_{0}$ が増大すると減少する.この ことは,前述したように波形勾配が大きくなると,平 均越波量よりも大きな越波量が現れる確率が高くな ることを示している.したがって, 直立護岸はh $/ \mathrm{L}_{0}$ の 増大よりも, $\mathrm{H}_{0} / \mathrm{L}_{0}$ の増大に対して好ましくない越波 特性をもっているといえよう.しかし,形状母数 $\alpha$ に 及ぼす波形勾配の影響は,前述ののり先水深・波長 比の場合ほど複雑ではない。

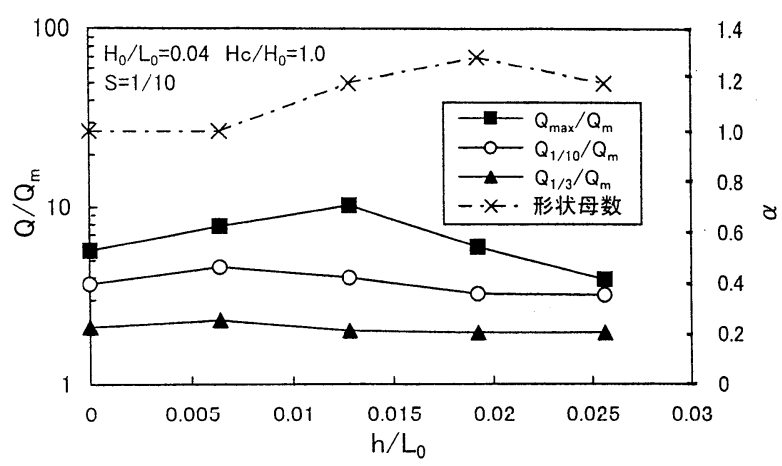

図-2 各代表越波量比および形状母数 $\alpha$ と のり先水深·波長比との関係

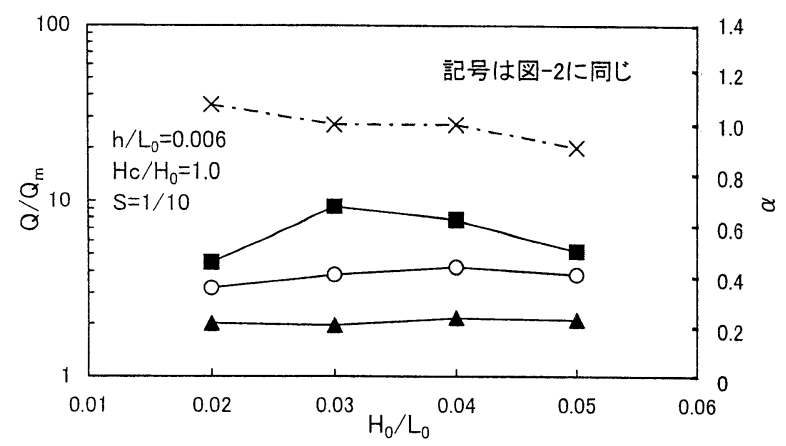

図-3 各代表越波量比および形状母数 $\alpha$ と 波形勾配との関係 
図-4には,各代表越波量比Q/ $Q_{m}$ および形状母数 $\alpha$ と相対護岸天端高 $\mathrm{H}_{\mathrm{c}} / \mathrm{H}_{0}$ との関係を示した。

これによると,いずれのQ/Q $Q_{m} も H_{c} / H_{0}$ が1.0に近づく ほど,大きくなる傾向がみられる.特に, $Q_{\max } / Q_{\text {m }}$ は $\mathrm{H}_{\mathrm{c}} / \mathrm{H}_{0}$ が0.6以上になると,その值は8〜10程度にもな る.形状母数 $\alpha$ は $\mathrm{H}_{\mathrm{c}} / \mathrm{H}_{0}$ が $0.2 \sim 0.6$ の範囲では減少 し, $\mathrm{H}_{\mathrm{c}} / \mathrm{H}_{0}$ が0.6の場合に0.8の最小值を示す.しか し, $\mathrm{H}_{\mathrm{c}} / \mathrm{H}_{0}$ が0.6以上になると増加する.このように,形 状母数 $\alpha$ に及ぼす相対護岸天端高の影響はきわめて 微妙であるため,直立護岸の機能設計に際しては,特 に注意が必要である。

図-5には,各代表越波量比Q/ $\mathrm{Q}_{\mathrm{m}}$ および形状母数 $\alpha$ と無次元風速 $\mathrm{V} / \sqrt{\mathrm{gH}} \mathrm{H}_{0}$ との関係を示した.

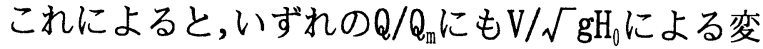
動はほとんどみられない.このように直立護岸の代 表越波量比に及ぼす風の影響は小さいといえる.形 状母数 $\alpha$ も $/ \sqrt{\mathrm{gH}_{0}}$ によって変動せず, 風の有無に関 わらず1.2以上と大きな值を示している.

このように, 直立護岸の $Q_{1 / 3} / Q_{m} や Q_{1 / 10} / Q_{m}$ には, $\mathrm{h} / \mathrm{L}_{0}$, $\mathrm{H}_{0} / \mathrm{L}_{0}$ および $\mathrm{H}_{\mathrm{c}} / \mathrm{H}_{0}$ の影響はあまりなく,ほぼ一定值を 示すのに対し, $Q_{\max } / Q_{\mathrm{m}}$ には,これらの 3 つの無次元量 の影響が大きい.なお,風の影響だけについては,ほ とんど考慮しなくてもよい.これらのことから, 平均 越波量だけを対象として, 海岸護岸を設計した場合, 排水設備が十分に整備されている場合にはあまり問 題はないが,そうでない場合には,例えわずか 1 波の 越波でも被災の可能性があるといえよう。

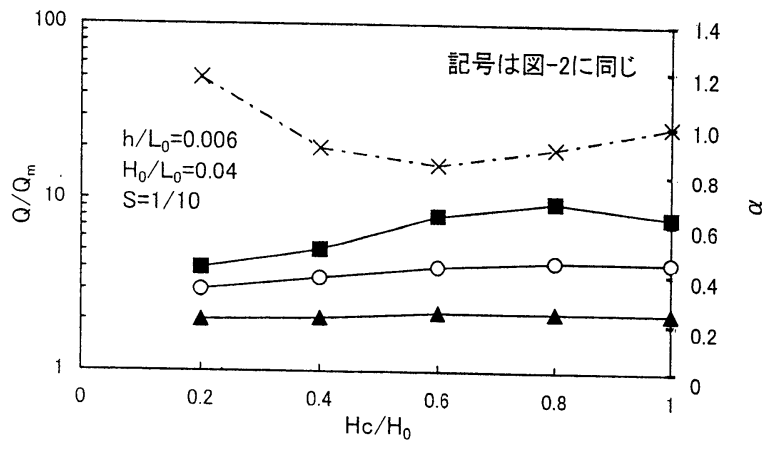

図-4 各代表越波量比および形状母数 $\alpha$ と 相対護岸天端高との関係

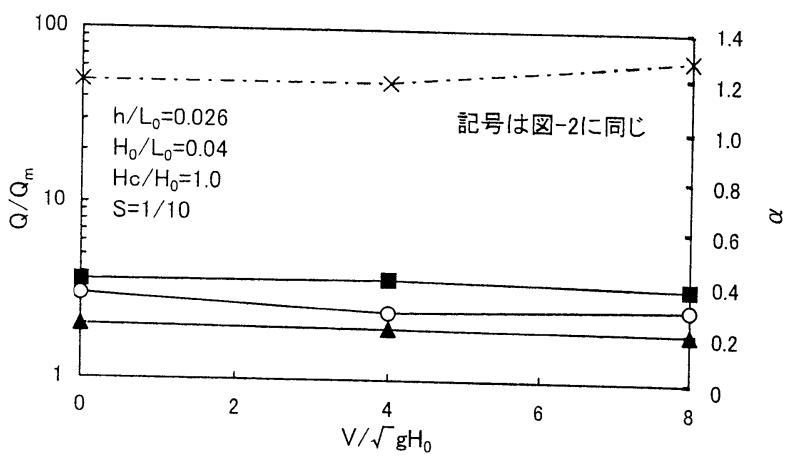

図-5 各代表越波量比および形状母数 $\alpha$ と 無次元風速との関係
（2）パラペット後退型護岸

1/50の傾斜海浜上に図-1(b)に示したものを設置 した場合について検討する.

図-6には,図-2と同様なものをパラペット後退型 護岸について示した.

これによると,いずれのQ/ $\mathrm{Q}_{\mathrm{m}}$ h/ $/ \mathrm{L}_{0}$ が0.103の場合 に最大值を示すが, $\mathrm{h} / \mathrm{L}_{0}$ による変動はほとんどみら れない.このように,パラペット後退型護岸の代表越 波量比に及ぼすのり先水深・波長比の影響は,直立 護岸の場合に比べて小さい.しかし,形状母数 $\alpha$ は $\mathrm{h} / \mathrm{L}_{0}$ によって大きく変動し, $\mathrm{h} / \mathrm{L}_{0}$ が0.103の場合に最 小值の $0.6 を$ 示している.このことは最大越波量に近 い越波量が現れる確率の高いことを意味しており， 注意が必要である.このように, $\mathrm{h} / \mathrm{L}_{0} に よ っ て$ 形状母 数 $\alpha$ が大きく異なる場合には,護岸の機能設計に際 して詳細な検討が必要である.

図-7には,図-5と同様なものを示した.

これによると,いずれのQ/蛼もV/ $\sqrt{ } \mathrm{gH}_{0}$ が増大して も変動はなく,ほぼ一定值を示す.形状母数 $\alpha$ も $\mathrm{V} / \sqrt{\mathrm{gH}_{0}}$ の増大とともに大きくなる.したがって,パ ラペット後退型護岸の越波特性に及ぼす風の影響は, 直立護岸の場合と同様に小さいといえる.

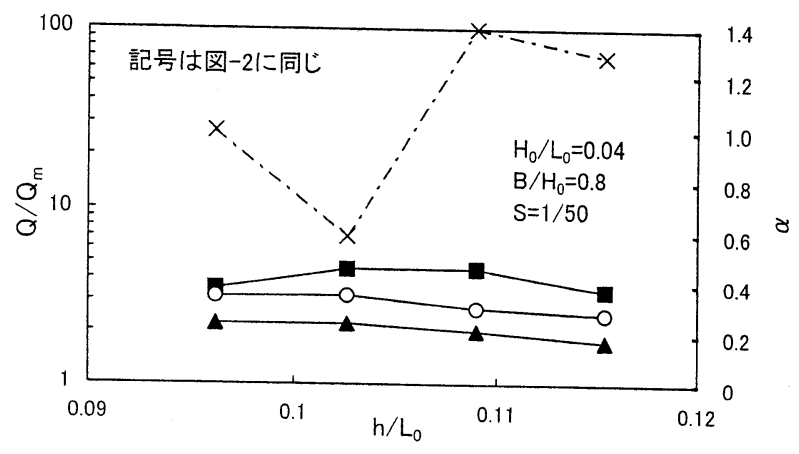

図-6 各代表越波量比および形状母数 $\alpha$ と のり先水深・波長比との関係

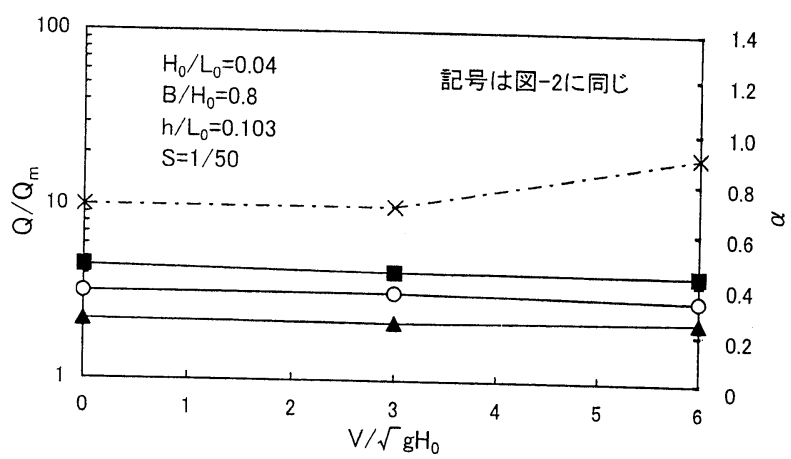

図-7 各代表越波量比および形状母数 $\alpha$ と 無次元風速との関係 
（3）有孔壁式護岸

1/50の傾斜海浜上に図-1(c)に示した有孔壁式護 岸を設置した場合について検討する。

図-8には,図-2と同様なものを有孔壁式護岸につ いて示した。

これによると, $Q_{1 / 3} / Q_{m}$ と $Q_{1 / 10} / Q_{m}$ にはh $/ \mathrm{L}_{0}$ による変動 はあまりみられないが, $Q_{\max } / Q_{m}$ は $/ \mathrm{L}_{0}$ が0.109の場合 に最大值の 6 となり, $\mathrm{h} / \mathrm{L}_{0}$ の影響がみられる.形状母 数 $\alpha$ は, $\mathrm{h} / \mathrm{L}_{0}$ が0.109の場合に最小值0.9を示す.この ように有孔壁式護岸についての形状母数 $\alpha$ は,のり 先水深・波長比の変化によって急激に変化するが, 形状母数そのものの值は大きい.

図-9には,図-3と同様なものを示した.

これによると, $\mathrm{H}_{0} / \mathrm{L}_{0}$ が0.03の場合には,いずれの $Q / Q_{m}$ にも差はほとんどなく,2程度の值を示す.しか し, $\mathrm{H}_{0} / \mathrm{L}_{0}$ が増大すると,いずれのQ/Q $\mathrm{Q}$ も増大する.特 に, $\mathrm{Q}_{\max } / \mathrm{Q}_{\mathrm{m}}$ は, $\mathrm{H}_{0} / \mathrm{L}_{0}$ の増大ともに単調増加し, $\mathrm{H}_{0} / \mathrm{L}_{0}$ が 0.05 の場合には,8程度にもなる.このように,波形勾 配が大きくなると防災上好ましくない特性を示すこ とは,この護岸の大きな欠点である.

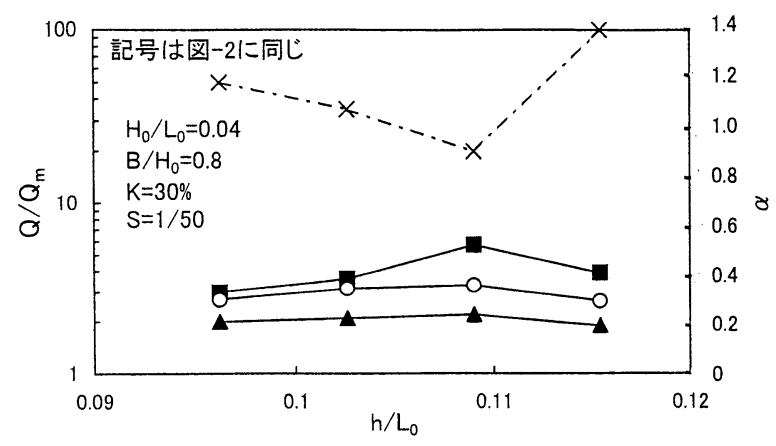

図-8 各代表越波量比および形状母数 $\alpha$ と のり先水深・波長比との関係

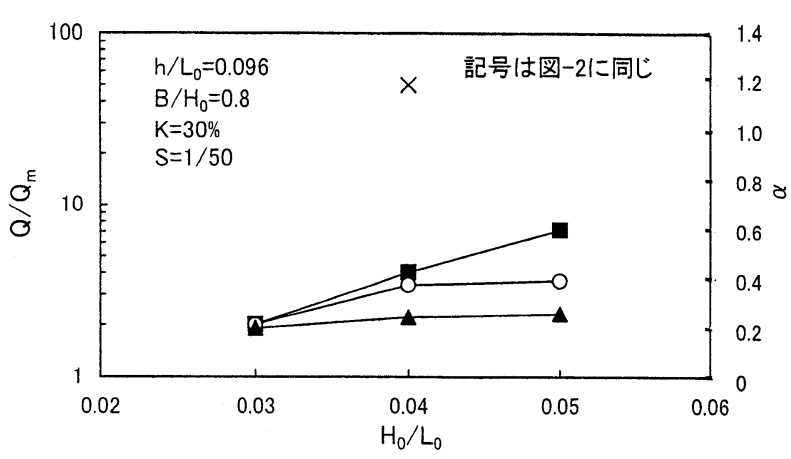

図-9 各代表越波量比および形状母数 $\alpha$ と 波形勾配との関係

図-10には,図-5と同様なものを示した.

これによると,いずれのQ/ $\mathrm{Q}_{\mathrm{m}}$ も $/ \sqrt{ } \mathrm{gH}_{0}$ の増大とと もにやや大きくなる.このように,有孔壁式護岸の各 代表越波量比に及ぼす風の影響は,前述したパラ ペット後退型護岸の場合よりも大きい.形状母数 $\alpha$
も $\mathrm{V} / \sqrt{\mathrm{gH}_{0}}$ が増大すると単調に減少する傾向を示す. このことも,防災上きわめて都合の悪い特性である.

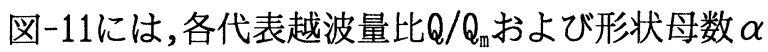
と護岸前面の開孔率Kとの関係を示した.

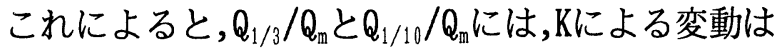
あまりみられないが, $Q_{\max } / Q_{m}$ は,Kが15\%までは増加 し,Kが $15 \%$ の場合に最大值を示し, $15 \%$ 以上になると 減少する.しかし,有孔壁式護岸の $\mathrm{Q}_{\mathrm{mx}} / \mathrm{Q}_{\mathrm{m}}$ に及ぼす護 岸前面の開孔率Kの影響はあまり大きくはない.形状 母数 $\alpha$ にもKによる変動はほとんどみられないが,そ の值は,0.5か0.6であり小さい.したがって,このこ とも有孔壁式護岸の欠点である.

図-12には,各代表越波量比Q/ $Q_{\mathrm{m}}$ および形状母数 $\alpha$ と無次元化した遊水部幅 $\mathrm{B} / \mathrm{H}_{0}$ との関係を示した.

これによると, $\mathrm{B} / \mathrm{H}_{0}$ が0.31から0.69の間では,いず れのQ/ $/ Q_{\mathbb{m}}$ に変動はあまりみられないが, $\mathrm{B} / \mathrm{H}_{0}$ が 0.69 よりも大きくなると,いずれのQ/Q $\mathbf{Q}_{\mathrm{m}}$ 若干減少する. すなわち, 有孔壁式護岸の遊水部幅を大きくすれば, 代表越波量比をやや小さくすることができる.形状 母数 $\alpha$ の $/ \mathrm{H}_{0}$ による変動はほとんどみられないが, その值は0.5か0.6で小さい.このことについても,前 述の開孔率の場合と同様のことがいえる.

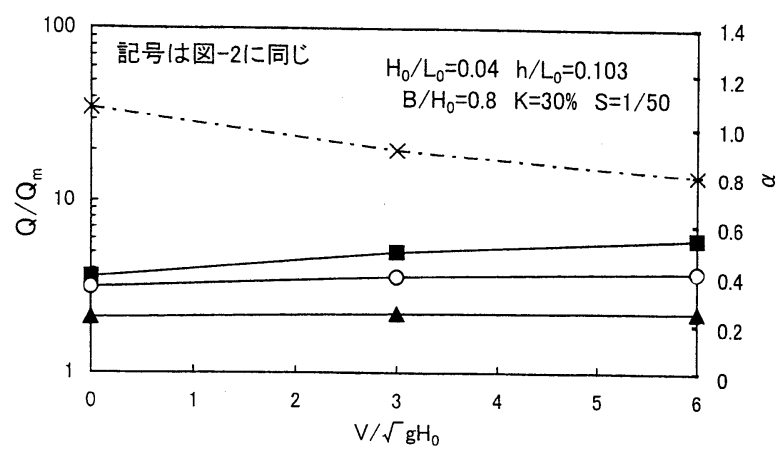

図-10 各代表越波量比および形状母数 $\alpha$ と 無次元風速との関係

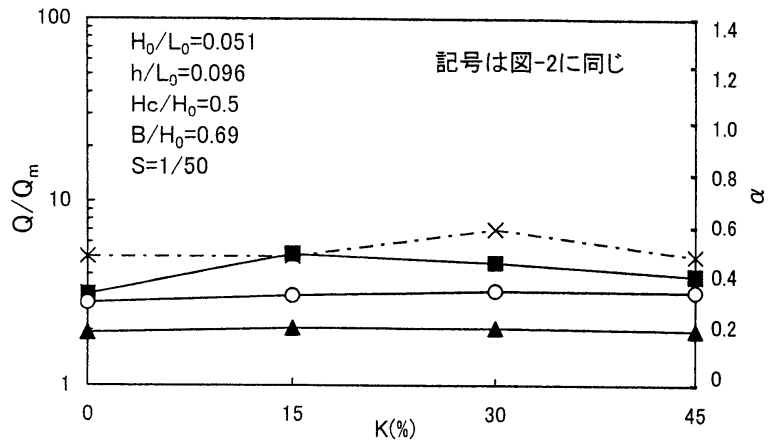

図-11 各代表越波量比および形状母数 $\alpha$ と 開孔率との関係 


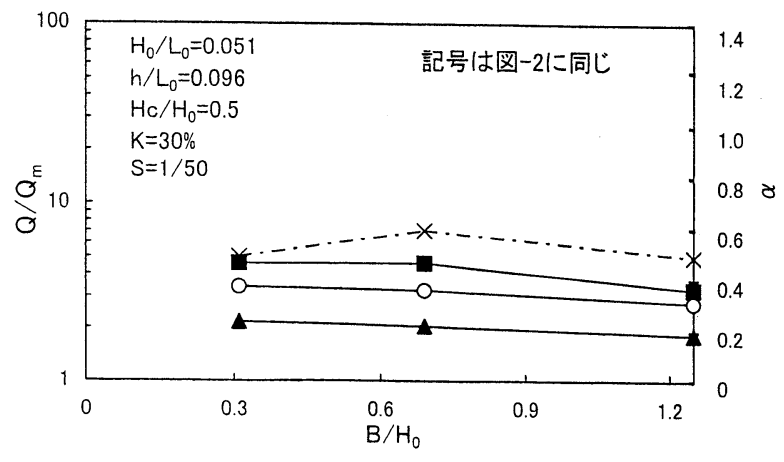

図-12 各代表越波量比および形状母数 $\alpha$ と 無次元遊水部幅との関係

\section{（4）3割勾配護岸}

$1 / 10$ の傾斜海浜上に図 $-1(d)$ に示した 3 割勾配護岸 を設置した場合について検討する.

図-13には,図-2と同様なものを示した。

これによると, $Q_{1 / 3} / Q_{m}$ は $/ \mathrm{L}_{0}$ によって,ほとんど変 動せず, 3 程度でほぼ一定值を示す.しかし,他のQ/Q はh/ $\mathrm{L}_{0}$ の増大とともに減少する傾向がみられ,特 に, $\mathrm{Q}_{\max } / \mathrm{Q}_{\mathrm{m}}$ は, $\mathrm{h} / \mathrm{L}_{0}$ が0の場合には10であるが, $\mathrm{h} / \mathrm{L}_{0}$ が 0.026 では5程度まで減少する.形状母数 $\alpha も \mathrm{~h} / \mathrm{L}_{0}$ が 增大すると大きくなり,変動範囲も大きい.このよう に, 3 割勾配護岸の形状母数 $\alpha$ に及ぼすのり先水深・ 波長比の影響は大きく, $\mathrm{h} / \mathrm{L}_{0}$ が大きくなると防災上 好ましい特性を示している。

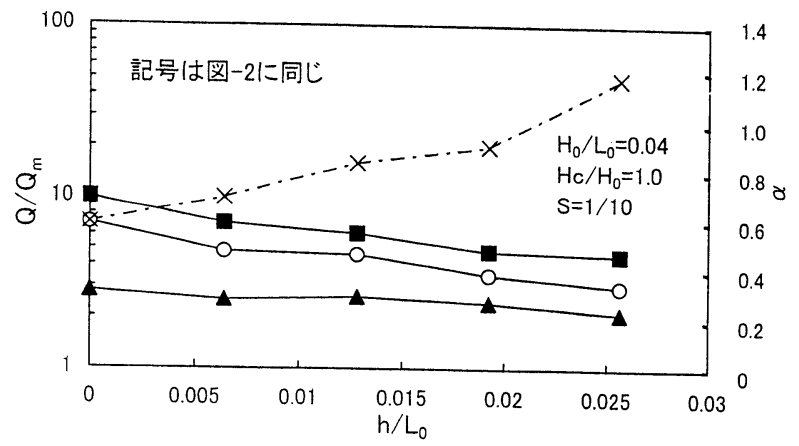

図-13 各代表越波量比および形状母数 $\alpha$ と のり先水深・波長比との関係

図-14には,図-5と同様なものを示した。

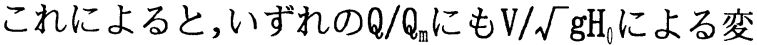
動はほとんどみられなく,3割勾配護岸の各代表越波 量比に及ぼす風の影響はほとんどないといえる.形

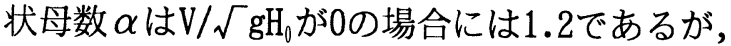

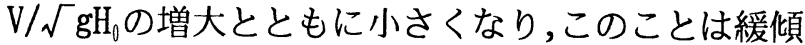
斜護岸の好ましくない越波特性である.

図-15には,各代表越波量比 $Q / Q_{\mathrm{m}}$ および形状母数 $\alpha$ とのり面の底質の中央粒径・波高比 $\mathrm{d} / \mathrm{H}_{0}$ との関係を 示した.

これによると, $Q_{1 / 3} / Q_{\mathrm{m}}$ と $Q_{1 / 10} / Q_{\mathrm{m}}$ は, $\mathrm{d} / \mathrm{H}_{0}$ によってあ まり変動しないが, $Q_{\max } / Q_{\mathrm{m}}$ は $\mathrm{d} / \mathrm{H}_{0}$ によって変動する. 特に, $\mathrm{d} / \mathrm{H}_{0}$ が0.0011や0.26の場合に大きくなり,6〜7
程度の值を示す.このように,のり面に透水性をもた せた場合, $\mathrm{Q}_{\max } / \mathrm{Q}_{\mathrm{m}}$ がd $/ \mathrm{H}_{0}$ によって微妙に変動したり， 形状母数 $\alpha$ も $d / \mathrm{H}_{0} に よ っ て$ 変化することは機能設計 上,注意しなければならない。

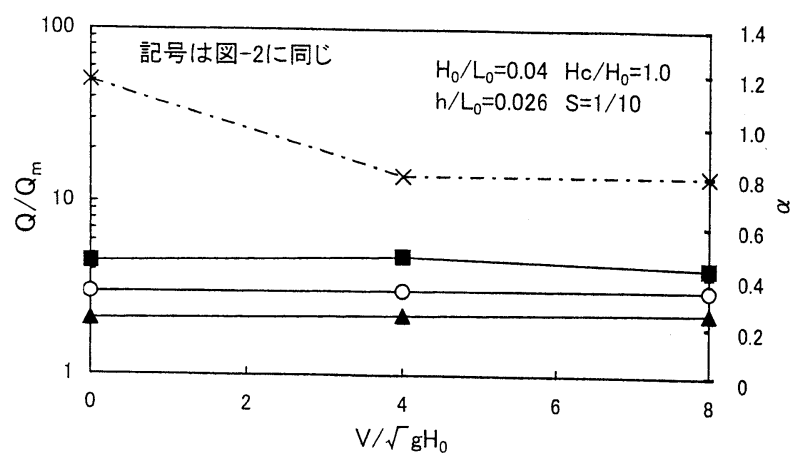

図-14 各代表越波量比および形状母数 $\alpha$ と 無次元風速との関係

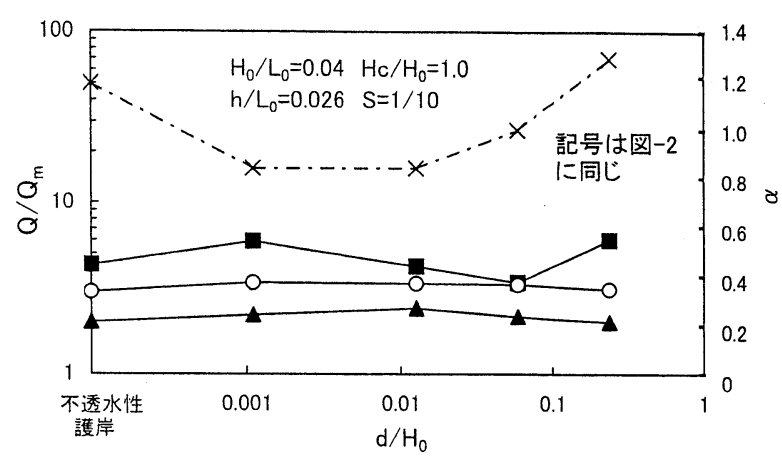

図-15 各代表越波量比および形状母数 $\alpha$ と 無次元粒径との関係

\section{（5）5割勾配護岸}

1/10の傾斜海浜上に図-1(e)に示した5割勾配護岸 を設置した場合について検討する。

図-16には,図-2と同様なものを示した。

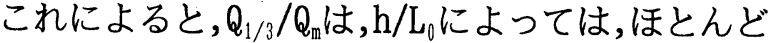
変動しなく,2〜3程度でほぼ一定值を示す.しか し, $Q_{1 / 10} / Q_{m}$ と $Q_{\max } / Q_{m}$ は, $\mathrm{h} / \mathrm{L}_{0}$ が0の場合には小さい が, $\mathrm{h} / \mathrm{L}_{0}$ が大きくなると若干増大する.

図-17には,図-5と同様なものを示した。

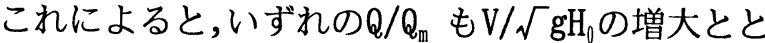
もに大きくなる.このように5割勾配護岸の場合には

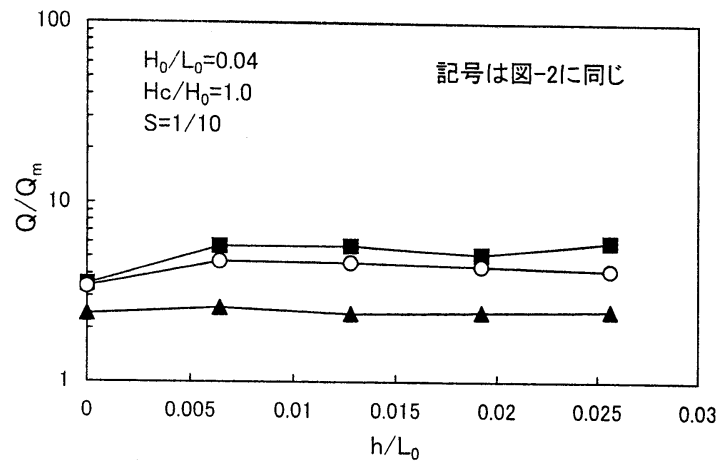

図-16 各代表越波量比とのり先水深 - 波長比 との関係 
風の影響がみられ,このことが3割勾配護岸との違い である。

図-18には,図-15と同様なものを示した。

これによると, $Q_{1 / 3} / Q_{\mathbb{m}}$ と $Q_{1 / 10} / Q_{m}$ にはd $/ \mathrm{H}_{0}$ による変動 はほとんどみられない.しかし， $Q_{\max } / \mathrm{Q}_{\mathrm{m}}$ はd $/ \mathrm{H}_{0}$ が0.001 以上になると大きくなり, $\mathrm{d} / \mathrm{H}_{0}$ が0.236の場合には10 程度にもなる。

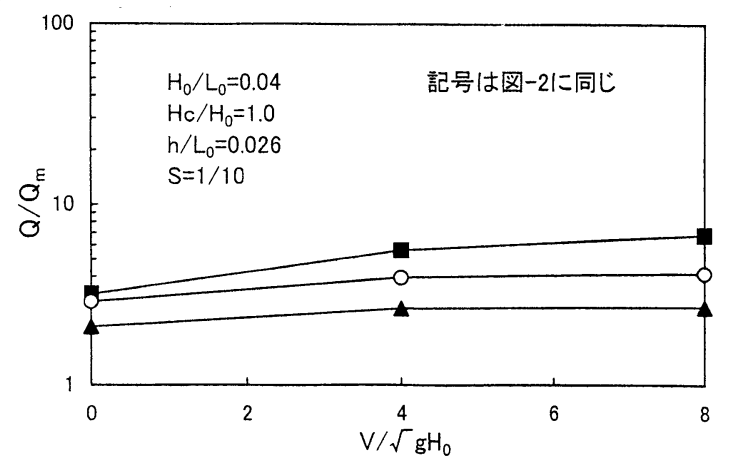

図-17 各代表越波量比と無次元風速との関係

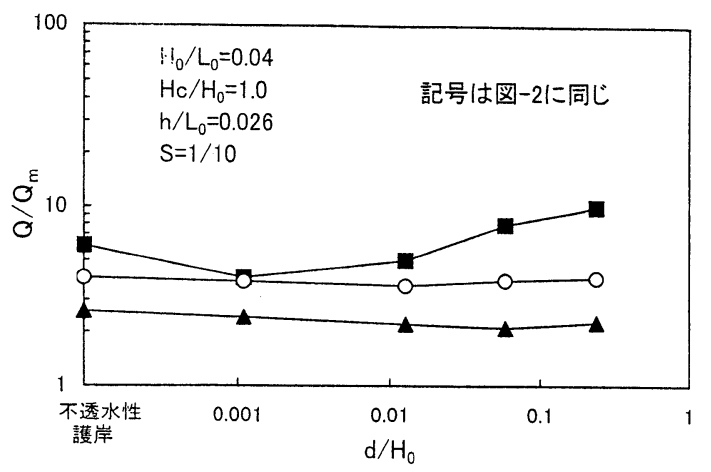

図-18 各代表越波量比と無次元粒径との関係

\section{4. 結 語}

以上,各種の海岸護岸における従来の実験結果を 用い,その時間的変動特性について検討を行ってき た.その結果,以下のようなことが明らかになった。

(1) 直立護岸 : $Q_{\max } / Q_{m}$ はのり先水深・波長比,波形 勾配および相対護岸天端高の影響が大きく,場合に よっては10程度にもなる.また,形状母数 $\alpha$ も前述の 3つの無次元量によって変化し,その值は0.9〜1.2で ある。

（2）パラペット後退型護岸 : いずれの代表越波量 比にものり先水深・波長比や風の影響はあまりない. しかし,形状母数 $\alpha$ はのり先水深・波長比によって 大きなばらつきがみられる。
（3）有孔壁式護岸 : $Q_{\max } / Q_{m}$ はのり先水深・波長比, 波形勾配および護岸前面の開孔率の影響がみられ， 特に波形勾配が大きくなる場合には防災上好ましく ない特性を示す.また,形状母数 $\alpha$ はのり先水深・波 長比によって大きく変動し,その変動範囲は0.9〜 1.4である。

（4）緩傾斜護岸 : 3 割勾配護岸の場合の $Q_{\max } / Q_{m}$ に及 ぼすのり先水深・波長比の影響は大きい.しかし,5 割勾配護岸の場合には,いずれのQ/ $\mathbf{Q}_{\mathrm{m}}$ にものり先水 深・波長比の変化による変動はあまりみられない。 しかし,のり面に透水性をもたせた場合の $Q_{\max } / Q_{m}$ は底 質の粒径によって大きく変動する。

\section{謝 辞}

この研究に用いた実験結果は,現在ニュージェッ クの殿最浩司氏, 大阪府の円間弘起氏, 坂本佳弘氏, 大阪市の野村義一氏, 東亜建設工業の藤野真人氏を はじめとする多くの関西大学海岸工学研究室の卒業 生諸君の研究によって得られたものであることを明 記して謝意を表する.また,この論文のとりまとめに は,島田広昭助手にもお世話になった。なお,この研 究には,関西大学学術研究助成基金を使用したこと も明記する。

\section{参考文献}

1）合田良実・岸良安治・神山 豊 : 不規則波によ る防波護岸の越波流量に関する実験的研究，運 輸省港湾技術研究所報告，第14巻，第4号， pp.3〜 44, 1975 .

2）井上雅夫・島田広昭・殿最浩司 : 不規則波にお ける越波量の出現頻度分布特性, 海岸工学論文 集，第36巻，pp.618～622，1989.

3）井上雅夫・島田広昭・円間弘起 : 透水性を有す る緩傾斜護岸の越波特性，海岸工学論文集，第 38巻, pp.541 545, 1991.

4）井上雅夫・島田広昭・円間弘起 : 緩傾斜護岸の 越波特性に及ぼす風の影響, 海岸工学論文集, 第39巻, pp.586〜 590, 1992 .

5）井上雅夫・島田広昭・坂本佳弘 : 親水性護岸の 越波防止機能,海岸工学論文集,第40巻, pp.701 〜 705, 1993.

6）井上雅夫・島田広昭・野村義一・渡会英明・上 山美登里 : 直立有孔壁護岸の越波特性とその越 波量の推算, 海岸工学論文集, 第43巻, pp.706 〜10, 1996. 